\title{
西行法師の花の歌一首の気候学的考察*
}

\author{
山本武 夫*
}

\section{Some Climatological Considerations about a Poem on Cherry Blossoms composed by Saigyo}

\section{By}

\section{TAKEO YAMAMOTO}

Saigyo (1118-1190), one of the most famous poets in Japan, composed a poem on cherry blossoms referring his death, which was collected in his anthology called "Sankashu". The meanings of the poetry are as followers;

It is to be desired that I should meet my end under the full bloomed cherry trees bathed in the full moon light of "Kisaragi" month.

The poem was likely versed in the later period of his life, though there is no records left to acertain when it was composed. The lunar-solar calender imported from Tang and noted by the name of "Senmei-Reki" was used at that time.

The dates of the 15 th of "Kisaragi", the second month in the ancient calendar, are converted to about a month or so later dates in the present solar calendar, though different year by year.

The cherry blossoms poem by Saigyo must be based on his experiences continuing several years or more, not on an extraordinary experience of one special case. At present the cherry trees come into full bloom generally in the first or second decade in April in the middle part of Japan. (see Table II) The solar calendar dates converted from the 15 th of "Kisaragi" seem to be remarkably earlier than the present flowering seasons of cherry trees.

Many authors have presented the hypothesis that a Little Climatic Optimum should exist in the period from the end of the XII century to the beinning of the XIII century, and, as seen in Fig. 3 (b), the last decade of Saigyo's life (1181-1190) coinsides to the peak of the winter character curve in England given by H. H. Lamb.

The percentage ratio of the snowy days to the whole precipitation days from November to March (henceforth "snowy days ratio") is entitled to be a reliable index for the heat and cold during the cold season in the ancient times (see Fig. 2) as well as at present. (see Fig. I)

The snowy days ratios computed by the data in "Gyokuyo", the diary written by Kanezane Kujo (1149-1207) give the estimations of every year warmth and coldness during the later part of Saigyo's life. (see Table 2) The averaged snowy days ratio in the period of

\footnotetext{
*山口大学教育学部地学教室。昭和 44 年 5 月 30 日山口国語国文学会にて講演。
} 註 (1) 以下歌の番号は伊藤嘉夫編「纂校山家集」による 
(1180-1184) is only $\mathrm{P}^{*}=11.5 \%$, being much smaller the whole period average of "Gyokuyo " $\overline{\mathrm{P}}=21.4 \%$.

Descending from Koya Mountain, Saigyo removed his dwelling to Ise Province in the spring of 1180 and lived there until his departure of his long journey to Ou provinces in the fall of 1186. Ise Province is located south east from Kyoto at a distance of about $110 \mathrm{Km}$. and the climate is respectably warmer in winter than Kyoto or Koya Mountain.

The full bloom dates of cherry trees (D) at Kyoto are computed by substituting the snowy ratios $(\mathrm{P})$ to the tentatively adopted equation

$$
\mathrm{D}=0.32 \mathrm{P}+3 \cdots \cdots(1)
$$

and the estimated full bloom dates at various places where Saigyo lived are compared with the converted solar calendar dates of the 15 th of the second month in the formar calendar. (see Table I) According to my opinion, Saigyo's famous poem on cherry blossoms in "Sanka-shu" is concluded to be composed at the end of his stay at Ise Province, for the peak of warmth during the Little Climatic Optimum around 1200 which was experienced in the warm regions of Ise can only make it possible that Saigyo could admire the cherry blossoms in the full moon light of "Kisaragi" month. I hope that the above conclusion might give some gleams for the solution of the questionable problems about the time when the compilation of "Sanka-shu" was completed.

If it is admitted to use the equation (1), the average flowering season of cherry trees at Kyoto in the period of "Gyokuyo" (1167-1200) in which $\overline{\mathrm{P}}=21.4 \%$ is estimated to be April 10, five days earlier than now. Consequently it is presumed that averaged mean air temperatures in February and March at that times should be about $2^{\circ} \mathrm{C}$ higher than today.

\section{1.はじめに}

西行の山家集の「花の歌女またよみけるに」と前書きした27首の中に

（88） 齐がはくば花の下にて春死なん

$$
\text { そのきさらぎのもち月の頃 }
$$

という一首註1)がある。この歌は俗に西行の辞世として人口に膾灾しているが, 文治三年 (1187A.D.) 彼が自 ら編んで藤原俊成の判を乞うた「御裳濯河歌合」に出ている歌であるから辞世と言うのは勿論正しくない。 当時使用されていた暦は唐の宣明暦である。太陰太陽暦であるから「きさらぎの望」と言つても現行の 太陽暦に換算すると, 年々大幅な遅速がある。しかし(88)の歌の「きさらぎの 望月のころ」の桜花期は, ある特別の一年の経験を言つているのではなく, 少くとも数年程度継続し, そのことが，作者にとつて既 にいはば気候学的常識となつていることを前提として考えなければならない。又如月の十五日は釈迦大滅 の日である。僧として恰度その日に示寂せんことを願つた気持は勿論あるとしても桜の満開と如月の望月 が当時の経験において若しひどく距つていたならば，この様な歌が制作される筈がないであろう。長い歳 月の間に気候が変動するということを考えないで現状の桜花季を標準に置いて考えて見ると「きさらぎの もち月の頃」は，桜花季に大分早すぎるのではないか言う疑問が湧く。この䀣念は，誰れにもあつたと見 えて佐々木信綱博士は「彼岸桜さきそめ, 満月の光うるはしい頃」という風に, 特別な花種をもつて来る ことによつてこの問題を解決しようとされている様である。

続本朝通鑑の文治三年 (1187A.D.) の条に前中納言藤成範の記事が出ている。 
『 $\cdots$...帰洛後。居樋口町。移芳野桜。栽其居之四面愛之。時人呼日桜町。 帝愛其風流。詔日桜 待中納言。花開則坐樹下。自朝至夕。猶為不足。終夜乗月賞之。……』

これを見ると, 当時の京都の人士が好んで栽培していた花種は, 芳野桜系統が主であつたように思わ れ註22, 又, その観賞の仕方も一身を終日終夜, 爛漫たる桜花に, 埋没すると言つた如き, 耽美的態度を理 想としていた様である。

西行の歌風は，当時の宮廷歌人の巧維を極め，技巧の粋を凝らすと言つた傾向のものとは対照的に，生 活体験を基本とし，素直に，おほらかに，毫も人為彫琢の跡をとどめない風格態度を，その特徴とする。 当時, 彼岸桜が一般に栽培されていたかどうか充分調查して見ないと分らないけれども，後鳥羽院が「生 得の歌人」「不可説言語の歌人」と賞讃したまうたこの曠古の大歌人を，一株の早咲きの彼岸桜の下に跼 跨せしめて考えることは, どうも似つかわしくなく, 矢張り爛漫たる桜花に埋もれて生滅流転の人生の衰 感を充分に歌つてもらいたいと思らのであるが，如何なものであろらか。

XII 世紀の後半から XIII 世紀の前半にかけて，世界の気候は，小最適期 (Little Climatic Optimum) であつたと言われている。しかも Lamb がイギリスの冬の気候の変遷について調べたところによれば西 行の晚年の 10 年間 (1181 A.D. 1190 A.D.) は偶然ながら，イギリスに於ける気候小最適時代の，その また最高峯部に当つているのである（第 3 図 [B]）。8 世紀むかしの日本の大歌人の作品を気候学的立場 から検討することも後の世に生れたものに課せられた任務のひとつであろう。

\section{2. 西行の伊勢移住について}

西行の晚年の，年々の寒暖は，九条兼実の「玉葉」にもとづいて，ある程度確実に 推定することが出 来る。第一表の [II] 欄に, 西行の晚年15年間の，年々の11月から 3 月までの 5 ケ月間の，降雪日数の全 降水日数に対する百分比（以下降雪率と呼ぶ）が揭げてある。このような “降雪率”が気候の 寒暖示数と して役立つかどうかは，京都気象台の観測值に関し（1929１930)～(1966 1967）の 38年分について調べ た第 1 図と, 近衛政家の「後法興院記」（1466 A.D.１505 A.D.）中の邸内の桜花満開日と降雪率の関係 をしらべた第 2 図を見て戴きたい。

「玉葉」の全期間I167 A.D. 1200A.D. の降雪率の平均值は $\overline{\mathrm{P}}=21.4 \%$ あるかか 西行の晚年の 15 年 の内1176A.D. 1179A.D. の 3 年間に比較的寒い年であり，1180A.D. 1184A.D の 5 年間は1181A.D. を 例外として, 著しい暖冬期であり, 1185A.D.〜1187A.D.の 3 年間は再び寒冬期に戻り, それ以後攻年の 1190A.D. まで再び暖冬期になつていることが分る。もつとも1189A.D. 年の降雪率は Nov. 5 Jan. 25 の期間（但し Jan. 4，17，20の 3 日のみあり）が久け，1190A.D. 年は Jan. 29へFeb. 14 および Mar. 12 以後が欠けているからこの 2 年については数字のそのままは当てにならない。但し1189 A.D. 年につい ては，「今年冬天甚和暖，昨日始有寒気」(文治四年十二月九日1189 A.D. Jan. 4) の記事より暖冬年と 推定される。1190 A.D. 年についても，2 月の前半と 3 月の後半の欠落の影響が相殺していると考えれば 降雪率の数字の示すごとく,どちらかと言へば暖冬年ではなかったかと思われる。

Fairbridge 第 3 図（A）や Lamb（第3 図B）の説および筆者の考えによれば，XII 世紀後半から， XIII 世紀の前半は気候の小最適期であつたらしい。「王葉」の全期間の平均降雪率にしてもこれを小水期 と考えられる室町時代の諸日記に比較すれば, 著しく小さいのである。1180A.D.〜1184A.D.の5 年間 の降雪率の平均值は $\mathrm{P}^{*}=11.5 \%$ で著しく低く日本の場合もこのあたりに Little Climatic Optimum の極 の存在していたらしいことを示唆している。この期間の降雪率の小さいことが日記の作者の観察や記録の 疎漏に因るものでないとは，この異常暖冬期のすぎた直後の年，寿永三年十二月六日 (1185A.D. Jan.16) の条に「自夜雪降末明開戸見之積地五六寸此五六年未有如此之雪」とあり又文治元年十二月廿六日（1186

註2）大後美保博士によれば，吉野山の桜はシロヤマザクラであり，日本人は江戸時代以前は大体ヤマザ クラの花を見て楽しんでいたということである。 


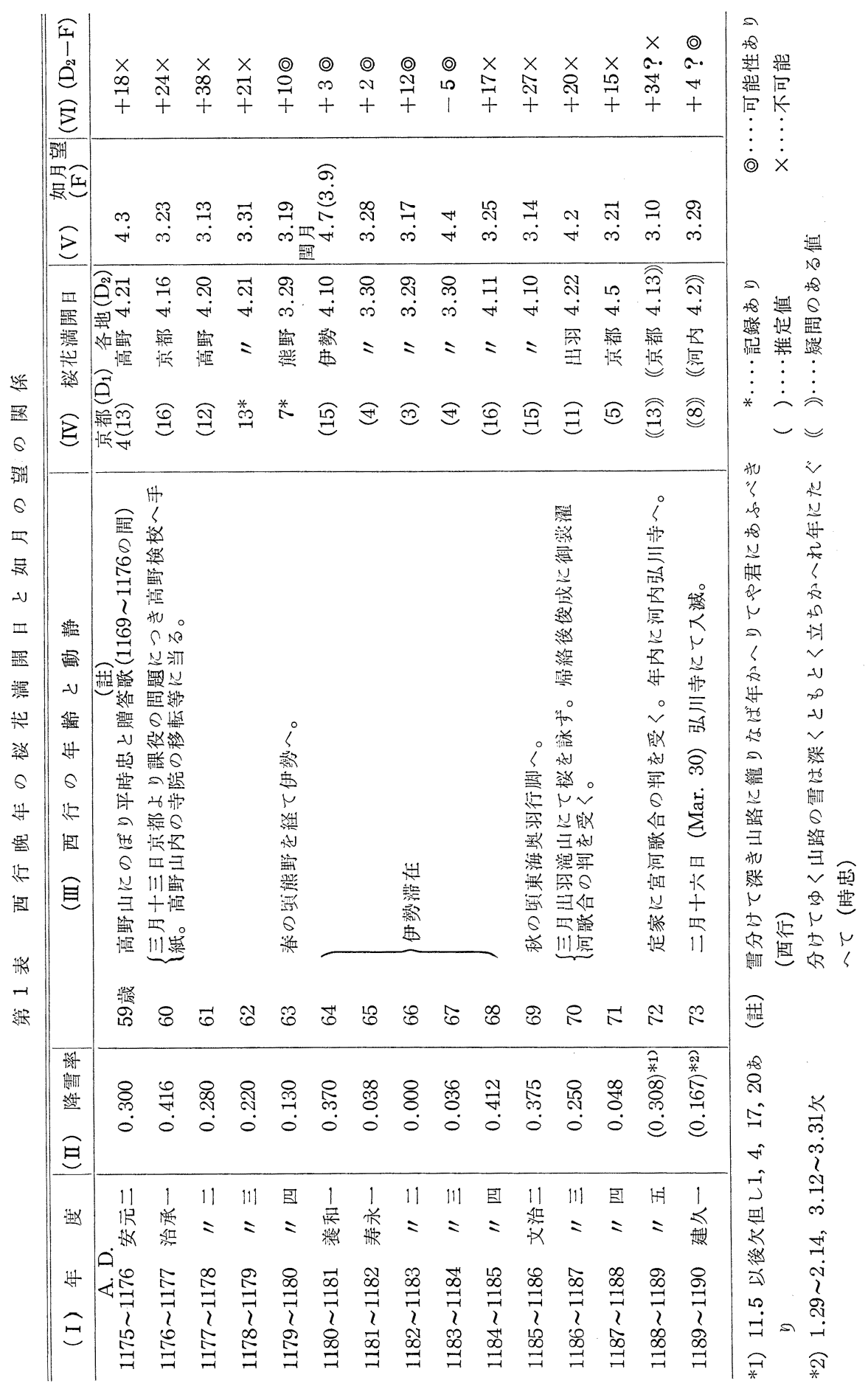




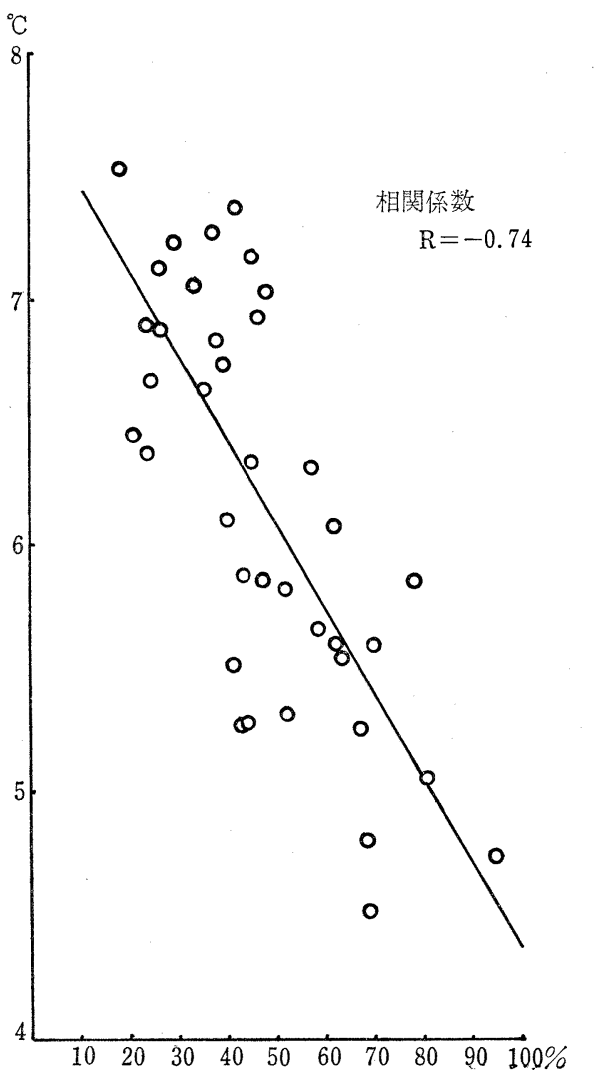

第 1 図京都に扮ける降雪率と気温の関係 (11月〜 3 月) $(1929 \sim 1930) \sim(1966$ 1969) $\mathrm{n}=38$

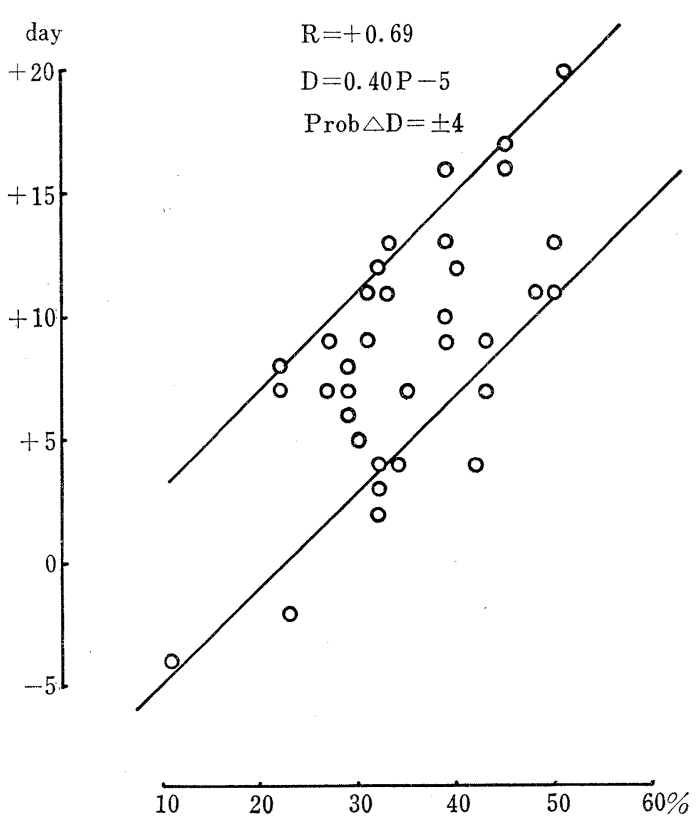

第 2 図 後法興院記の降雪率と桜花季

A.D. Jan. 25）の条に「夜雪高積殆及尺近年之間彙少之甚雪也」等とある。「玉葉」の記事によつて充分 納得することが出来よう。

第一表 (IV) 欄の西行の動静は, 主として, 川田順著「西行」の年表に従つたものである。

風巻景次郎著「西行」窪田章一著「西行の研究」も参照したが, 窪田博士の意見は, 川田, 風巻の二著 と若干異る点がある。その食違いの点は, 筆者が, 自己の判断に従つて 取捨した。西行は治承四年 (1180 A.D.）高野山を降りて伊勢に向い，源平争霸の動乱の数年間を伊勢二見浦の付近で過し，文治二年（1186 A.D.) 69歳の高齢をもつて再度の奥羽旅行に出発するのである。この辺のところは，諸家の意見が一致し 格別の疑義は生じない部分である。ここで重要なことは，先に述べた異常暖冬期間（1180A.D. 1184A. D.) が，西行の晚年の伊勢在住期間（1180A.D.〜1186AD.) と偶然にも重なつていることである。伊勢は 京都よりも気候温暖の地で桜花季も5 日位早い。これらのことは, 従来あまり顧みられなかつた点である が，(88）の歌の「きさらぎの望月の頃」の桜花季を論ずるに当り，是非とも考慮に大れられなければな らないことと筆者は考えるのである。

以下山家集の歌や詞書によつて，西行の高野から伊勢への旅行の足跡を追つて見ることにしよう。 熊野へまかりけるに やがみの王子新》の花おもしろかりければ 社に書きつけける

註3）現在の田辺市付近 


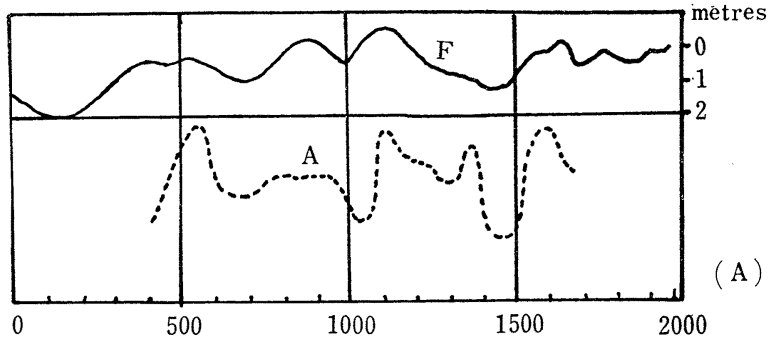

(A) F： Fairbridge に拠る海面水準の変化，A：オーロラの活動の推移(F. Link に拠る)

(B)

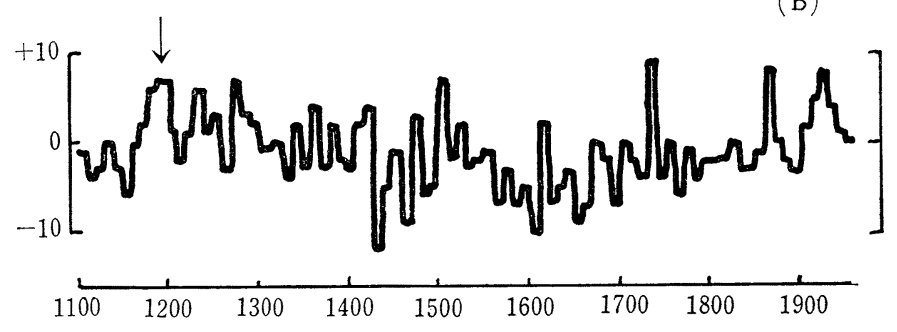

(B) 1100-1939年間の各10年間のイングランドにおける冬の温暖/寒冷指数の推移。(H.H. Lambに拠る) ( $\downarrow$ は西行の生涯の最後の10年間を示す)

第 3 図歴史時代の気候変動

（109） 待ちきつるやがみの桜咲きにけり あらくおろすなみすの山風

那智に籠りて滝に入堂し侍りけるにこのうえに一二の滝おはします。それへまみるなりと申す常

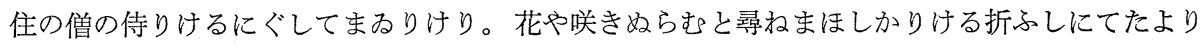
あるここちして分けまるりたり……... (後略)

(924) 木のもとに住みけむ跡をみつるかな 那智の高嶺の花を辈ねて

偶々この年治承四年の春藤原定家の「明月記」に桜花季が記録されている。

『三月四日 (1180A.D. Apr. 7) 天晴夕雨降……近日花盛 咳病猶不出仕……』

と言うのがそれである。南紀の花季恃京都より約10日位早いから西行がやがみの王子社に詣でたのは二月 下旬であつたと推定される。それから本宮に参詣して船で新宮に下り那智の滝に籠つたり那智山 (909M) の高処に春遅く咲く花を訪ねたりしている内に三月の上旬になつていただろらと思われる註4。

新宮より伊勢の方へまかりけるに みきしまにふねのさたしける浦人のくろきかみはひとすぢも なかりけるをよびよせて

（1488）としへたるうらのあま人こととはむ＼cjkstart波をから゙きていくよ過ぎにき

この歌の “みきしま”は，現在の三木崎付近になるのではあるまいか。さうだとすると，新宮から徒歩 熊野浦に沿つて約10里の道を歩いた後, 晚春の海路を伊勢に向つたことになり, 伊勢到着は三月の中旬頃 と言う推定になる。

伊勢にまかりたりけるにみつと申所にて 海辺の春の暮と云事を神主どもよみけるに

(191) すぐる春しほのみつよりふなでして なみのはなをやさきにたつらむ

みつは伊勢度会郡二見村である。大神宮の神官に西行の歌の門人が多かつたのであるから，恐らくこの 歌は, 西行の到着の歓迎の歌会の作品と思われるが, 歌の内容から, 季節は三月の未であり, 上述の旅程

註4）藤原定家の随行した後鳥羽上皇の熊野御幸(建仁元年 1201 A.D.) の場合は田边那智の間が 7 日の 行程である。 
の日時の順序によく照合することになる。西行の伊勢移住を治承四年とするのは，平家の福原遷都（治承 四年六月二日）について，異本山家集の中に

福原へ都遷りありと聞きし頃 伊勢にて月の歌よみ待りしに

(2124) 雲の上やふるき都になりにけりすむらむ月の影はかはらで

の歌を根拠とするのである。

\section{3.「そのきさらぎの望月のころ」は桜花季となり得るか}

「玉葉」についても第 2 図に示した如き，降雪率と桜花季の関係を求めたいのであるが，残念ながら 「玉葉」の期間には，桜花季の記録が寡く，僅かに前にあげた治承四年の「明召記」の記事とその前年治 承三年の

二月廿九日 (1179A.D. Apr. 13) 帝御南殿贸花命蔵人頭源通親等近臣各賦詩聯句（本朝通鑑）内 裏侍臣見大内桜花（百鍊抄）

の二個しかない。この二つのデーターを満足するように桜の満開日 (D) と降雪率 (P) の関係式を作つ て見ると

$$
\mathrm{D}=0.32 \mathrm{P}+3 \cdots \cdots(1)
$$

となる。（1）式に従えば寿永二年 (1183A.D.) の如く「玉葉」に降雪記録の皆無の異常暖冬年の桜花季 はApr. 3 と言うことになる。1100年代の桜花 季の記録は，筆者の調べた範囲では，8個あり その中で一番早いのは，天治元年 (1124A.D.) の閏二月十二日「両院臨幸法勝寺覽春花」の Apr. 5 である。川田順氏は康治元年二月廿六 日 (1142 A.D. Apr. 1) の待賢門院の御落飾 について「桜花爛漫の頃」と記述されている が, 若しこれが単なる川田氏の文飾でなく，何 等かの古記録に拠つていられるのであるなら ばこのApr. 1 が1100年代で一番早い桜花季 の記録といらことになる。(1)式は少数のデー ターに基く信用度の薄いものであるが，一応の 思考の基準を与える式として採用することに

第 2 表 染井吉野桜の花季（大後博士による）

\begin{tabular}{|c|c|c|c|c|c|}
\hline \multicolumn{2}{|c|}{ 場 } & 所 & 開 花 日 & 満 開 日 & 統計年数 \\
\hline 彦 & & 根 & $12^{4 \text { 月 }}$ & $18^{4 \text { 月 }}$ & 13 \\
\hline 京 & & 都 & 8 & 15 & 26 \\
\hline 大 & & 阪 & 2 & 14 & 14 \\
\hline 橿 & & 原 & 2 & 14 & 14 \\
\hline 和 & 歌 & 山 & 4 & 9 & 8 \\
\hline 名 & 古 & 屋 & 4 & 12 & 16 \\
\hline 亀 & & 山 & 3 & 10 & 9 \\
\hline & 津 & & 4 & 11 & 14 \\
\hline 平 & & 均 & 4 月 5 & 4 月 13 & \\
\hline
\end{tabular}

し，第一表 IV 欄 $\left(\mathrm{D}_{1}\right)$ に京都の桜花満開日を計算して見た。桜の開花日と満開日は第二表に引用した 如〈註5) 場所によつて違い又高度によつても左右される。現代の京都と各地の満開日の平均差, 高度によ る変化の係数等を用いて当時の各地の桜の満開日を推定したのが $\left(\mathrm{D}_{2}\right)$ である。高野山は京都と和歌山と の地域差と中原孫吉博士の式の高度係数 1.6 日 $/ 100$ 米につき $\mathrm{h}=900 \mathrm{M}$ として計算した高度変化を併して 結局十 8 日となつた。伊勢坆第二表の津と和歌山の平均値をとりー 5 日となる。羽前最上郡滝山は，秋田 の平均満開日Apr.28（n=26）と新潟の平均満開日 Apr. 23( $\mathrm{n}=14)$ の平均值を用い+11日とした。

又の年の三月に，出羽の国に越えて たきの山と申す山寺に侍りける 桜の常よりも薄紅の色こ き花にて なみたてりけるを 寺の人々と見興じければ

(1219）たぐひなき思ひいでばの桜かな うすくれなるの花のにほひは

の桜花満開日の推定は若し川田，風巻氏の年表を用いれば1187 A.D. Apr. 22 (文治三年三月五日）とな

註5）大後美保博士による。ソメイヨシノは江戸時代巣鴨染井の植木屋の養成したものと云われ，その花 季は山桜と多少前後するが, 統計資料の整備している関倸上, ここではソメイヨシノ桜の場合を引 用した。 
る。この桜は八重桜系統の花とも考えられる。若しそうだとすると満開日汶数日遅れることになる。しか しいずれにせよ歌の詞書きの三月に一致する。(V) 欄には各年の二月望（十五日）を現行太陽暦に換算し た日付 $(\mathrm{F})$ が記入してある。(VI) 欄の $\left(\mathrm{D}_{2}-\mathrm{F}\right)$ を見れば西行が「きさらぎの望月」の下に爛漫たる桜花 を眺めることが出来たかどらかを判定する一応の基準が得られる。符号の十は桜の満開日が「きさらぎの 望」以後になる日数, 一は以前になる日数をあらわす。桜の満開日は勿論寒候季の降雪率のみで一義的に 定るような単純なものではなく第 2 図の場合も，蓋然誤差 $4 \mathrm{D}= \pm 4$ 日 程度で成立している関係であ る。(1) 式についても蓋然誤差士 4 日とし推定満開日の前後 3 日位は桜花の爛漫状態が眺められると仮 定し，これらの範囲でもつとも都合のよい場合について桜花の爛漫状態が「きさらぎの望」と土 5 日の範 囲で重り得る可能性を検討して見ると1176A.D.〜1179A.D. の高野時代は不可能であり 1180A.D. の熊野 と1181A.D. 1184A.D. の伊勢時代の 5 年間は可能となる。それ以後の数年も不可能であり歿年の 1190 年は, 若し日数の欠けている降雪率 $\mathrm{P}=0.167$ を採用してよければその可能性が与えられ藤原俊成の「長 秋詠藻」中の『願ひおきし花の下にて終りける蓮の上もたがはざらなむ』が真実ということになる。

筆者は熊野から伊勢にかけて西行が如月の望月の下に迎えた数回の桜花季の経験の累積が，ひとつの常 識として（88）の歌を詠じた心理の深層に横たわつていたと考えたい。若し然りとすれば（88）の歌の制 作は，伊勢在住期間の末着永三年か四年頃と言うことになる。文治二年 (1186A.D.) 西行注69歳の老齢を もつて伊勢を発つて奥羽への旅へ登るのである。

（2130）年たけて又こゅべしと思ひきや

命なりけりさやの中山

(2138）風になびく富士の煙の空にきえて

行方も知らぬ我思ひかな

等はそのときの筹旅歌である。慈円（1155A.D.〜1285A.D.）の「拾玉集」には

『願はくは花のもとにて我死なむ其のきさらぎの望月のころとよみおきてそれにたがは妨ことをせ

もあはれがりけり。又風に犘く富士の煙の空に消えて行方も知らぬ我思ひかなも此の二三年の程によ

みたり。』

この記事は，（88）の歌と（2138）の歌の製作があまり距つていないことを暗示している。又内容的に も（88）と（2130）(2138）には共通する心境がうかがわれるのである。すなわち悠久な自然に寄する人身 のはかなさを詠じ哀韻漂渺たる点に於て三首とも互に関連し合つた心境の所産であるように思われるので 亦る。

以上を綜合すると西行にとつて「きさらぎの望月のころ」が桜花季であり得たのは，

（i ） 1100A.D.代の後半から1200A.D. 年代にかけては日本に於ても気候の小最適期があつたこと。玉 葉（1167A.D. 1200A.D.）の平均降雪率注 $\overline{\mathrm{P}}=21.4 \%$ （1）式に適用することを許されるならば 桜の平均満開日は $\overline{\mathrm{D}}=10$ となり現代より 5 日はやく 2 月と 3 月の平均気温に換算して $2{ }^{\circ} \mathrm{C}$ 程度温暖で あつたことを意味する。勿論これは一応の推定值であるが。

(ii）その中でも，特に，西行の瑤年（1190A.D.）の10年前頃から数年閒異常暖冬の継続した期間があ つたこと。このことは Lambのイギリスに於ける winter character 曲線の peak とほぼ完全に一 致している。(第 3 図B)。

(iii）たまたま西行が，この様な異常暖冬期間を含む数年間を伊勢に在住したこと。染井吉野桜につい

て刍山や津の平均満開日は京都よりも5 日位早い。

以上の三つが重複することによつて実現したと考えられる。

建仁元年 (1201A.D.) 藤原定家が鳥羽上皇の熊野御幸に扈従したときの日記には「十月十日（Nov. 14)」「夜法初冬というに暑く三伏に異ならず䖧む夏の如く多い」と言う意味のことが記録されている。 先に述べた藤中納言の京都に於ける月光の下の終夜の観桜と言ひいずれも寒候季の気候が温暖であつたこ 
とを暗示している。又定家の「明月記」には京都の井水の枯涸や旱損の記事が屡々出て来る(1199A.D. 1204A.D. 1226A.D. 1229A.D. 1233A.D.)。

こ机等は, 北太平洋高気圧が年間を通じてつよく日本列島の気候が西熱帯化していたことを推察させる のであるが，Lamb のイギリス気候の場合とよく一致していることを併せ考えると，中緯度高気圧の拡大 が，世界的規模で起つていたらしいと言うことになる。かく考えて来ると，西行法師の（88）「願はくば 花のもとにて……」の一首の含蓄するところ, 決して狭少とは言えないのである。

\section{4. 山家集の成立について}

山家集には，六家集本山家集と異本山家集があるが，この二種の山家集に先行する西行の家集と言つた ものが存在していたであるうと想像されている。竹柏園所蔵の古鈔残閶本山家集の奥書に『本書本云。山 家集歌三千百十二首也。其下より三重集をばえらび出られたるなり。…… (中略) $\cdots \cdots \cdots$. 正本は奈 良伊勢にぞ侍るなる。尋祇とりて書かるべし。』市るのが恐らくそれに該当するものであららが，この 「正本」は，約 8 世紀の歳月に埋もれて現在その所在が分らない。この様な家集の成立について 風巻景二郎 氏は「全体としての見透しから言つて，晚年伊勢在住の頃奥羽行脚前には出来ていたらしく思われる」と 考光られ，川田順氏は「伊勢閑居中最も大切な仕事は，おそらく彼が家集を自編したであららといらこと である。両歌合せ如きは此仕事の副産物であつたと考えられる。と述べていられる。（88）の歌は，六家 集本山家集にも異本山家集にも出て居り, 前に述べた如く御裳濯川歌合にも自選されている。従つて若し この歌が，筆者の推定した如く伊勢在住の異常暖冬期の未期，すなわち，寿永三年か四年頃に製作された ものだとすれば，家集の成立を，伊勢時代の末，奥羽旅行の前に置く風巻，川田雨氏の考えとよく調和す ることになる。七旬仪近い高噛の身をむつて奥羽千里の旅に出で立をんとして定めなき生死のことを抢も い, この際生涯の作品に整理をつけて置こうと考光るのは, 極めて自然なる心情とも言へ上う。

然しながらこれと異る考えもあるのであつて，隻田章一郎博士は，六家集本山家集（流布本山家集）の 成立は「伊勢に移る前で打切られ」「おそらく高野山に生活の本扰を置いた時期の終りであつた」と考察 していられる。従つて䆶田博士の結論としては，（88）の歌は「睌年になつてのものではない。」(「西行 の研究」 p. 579）と言う推定に至るのである。筆者の上述したところと篗田博士のこの考えは，いずれが 正否であるかは別として, 両立し得ないものであるから, 筆者と雖も, いささか蝠螂の紊を振つて, 反諭 を試みざるを得ない。

寉田博士によれば「伊勢定住時代から晚年の10年間の作品は, 山家集中のものがー首も検出されない」 と言う立場を固持していられる。果してそうであろうか。䆶田博士の検出と言われるのは，極めて祳密な 科学的な意味に於てである。しかし積極的に立証するものが無いと言うことは，あるか無いか分らないと 言うことであって無いと言うことではない。

筆者は 2.の敊わりに，西行が高野山を下つて，伊勢に向う途中の，旅程と季節の 推移を（109）(924) (1488) (191）の順に並べることによつて無理なく理解出来ることを述べた。これらの歌はすべて山家集所 載のもので, 明らかに高野下山以後のものである。勿論, 窪田説の如く「それ以前に伊勢に旅をした折の 作品」と言う解釈も成立しない訳ではない。いずれが正しいかは, 特別な科学的根拠がある訳ではないか ら結局は，判断の問題ということになるであろら。

伊勢に斉王おはしまさで年終にけり 斉宮, 木立ばかりさはと見えてつい坦も無きやうなりたり けるを見て

(1315) いっかまたいっきの宮のいっかれて しめのみらちに麼をはらはむ

も亦「山家集」中のものである。伊勢に斉宫のいらせられなかつたのは, 承安元年 (1171A.D.) 八月以降 文治三年 (1187A.D.) までの16年間である。若しこの歌が西行晚年の伊勢在住期間でないと仮定すると， 1180A.D.（治承三年）以前，すなわち1171A.D.〜1179A.D.の足掛け 9 年間でなければならないが「年経 
にけり」の前書きより初年度は勿論問題にならず，その次の1172A.D. は清盛に招かれて摄津へ旅行した 年であり，1177A.D. (治承元年) 以降伊勢への出発をでは, 高野山で暮らしたことがほぼ確実であるから （第一表参照）残りは 4 年註6)と言うことになる。この間に西行が伊勢に旅をしたという積極的証拠はな く, しかも (1315) の歌の詞書きはどちらかと言うと, 定住者の観察の樣である。尾山篤次郎氏は, 「お そらく治承寿永のころの作」と推定していられるが，西行が少くとも治承元年 (1177A.D.) 以後治承四年 (1180A.D.) 春まで高野山で生活していたとすれば，結局晚年伊勢在住時代の作品ということになるであ ろう。山家集には嚕年伊勢在住以後のものは一首もないとする説は, この辺からも崩れさうである。睍年 伊勢時代の作品の全部が家集に収められなかつたのは, 奥羽への長途の旅への準備に忙しくなり, 未整昹 の作品や推敲の余地あるすのを後に遺さざるを得なくなつたためで，この時代の作品は，山家集の中に他 にもあると私は考えたい。

最後にもら一つ問題がある。風巻説の如く家集の成立を 奥羽行脚前とすると，「山家集」に出ている （1219）出羽国滝山の観桜の歌を文治三年三月とすることに, 当然疑問が生ずることになる。風巻氏の作 成された年表と所説は矛盾を蔵していると言えよう。その点窪田博士の立場ははつきりしていて (1219) を前回の奥羽旅行の作品とし，久安四年 (1148A.D.) の製作としていられる。若しそうだとすると，その 前年の冬，西行は平泉に着いたことになり，「ゆきふりあらしはげしく」「汀凍りてとりわきさえけれ ば」と詞書きした歌を作つているから1147A.D.〜1148A.D. の冬は少くとも暖冬年ではなかつたと考えら れ, 久安四年の桜花季は, 現代の平年值として前に推定した Apr. 26以前ではなかつたであろう。然るに, 久安四年の三月け現行曆で（Mar 29 Apr. 26）の間であるから,詞書きどほり三月に観桜したとしても, ギリギり一杯と言うことになり，いささか問題である様である。この歌は，気候学的に考えれば，むしろ 従来の説のとほり文治三年として置く方がいい様に考光られる。旅程の方も秋伊勢を発つて八月十五日鎌 倉着頼朝に謁し (吾妻鏡) 十月十二日平泉へ到着したとするのは極めて自然である。若し然りとすれば， 山家集は奥羽旅行の作品も含んでいることになる。そうすると西行の家集なるものは，奥羽行脚出発前伊 勢で一応完成したが，それに若干の旅中の作品を加えて集成されたものが，西行の座右に置かれ，最晚年 の他の未整理の歌稿とともに，舀後門人や歌友に遺されていたのではあるまいか。その原本から色々の立 場の人々の手によつて抄出されたものが，「六家集本山家集」「巽本山家集」「山家心中集」「聞書集」 等となって後世に伝り，原本自体は紛失してしまつたと言う関係になるのではあるまいか。以上は素人の 一私見にすぎず，専門の方の御高教を仰ぎたいものだと思つている。唯この一文の㥞な気候学的な考え方 も今後問題解決の一助になるであろうことを期待しつつ筆を蘭きたい。

\section{照 文 献}

R. W. Fairbridge: Mean sea level relatated to solar radiation during the last 20000 years.

Proceeding the Rome Symposium organized by Unesco and the W. M. O. 1963.

H. H. LAMB: The Changing Climate, London, 1966.

F. LINK: Variations climatiques et salaires dans le passe historiqué. L'Astronomie Août. Sept, 1968.

大後美保, 鈴木雄次 : 日本生物季節論. 北隆館, 昭和 22 年.

大後美保：季節の事典. 東京堂, 昭和 36 年.

伊東嘉夫校註：山家集. 朝日新聞社編刊, 日本古典全書, 昭和 22 年.

川田順 : 西行. 創元社, 昭和 14 年.

川田順：西行伝. 西行全集，文明社，昭和 16 年，p. $25 \sim$ p: 55 .

風巻景二郎：西行. 建設社, 昭和 22 年.

（註6）安元元年（1175A.D.）鳥羽法皇御追善の為皇女頌子内親王が高野東別所に蓮華乗院の建立を命ぜ られた大義房賢宗が示寂した後西行が事務を継行(女院御寄附文具書, 建久五年斉院庁宣) している からこの 4 年はもつと縮められるであらう。 
窪田章一郎: 西行の研究. 東京堂, 昭和 36 年.

尾山篤二郎: 西行法師評伝. 改造社, 昭和 9 年.

佐々木信網校訂：新撰山家集. 岩波書店, 昭和 3 年.

佐々木信綱: 西行総説. 西行全集, 文明社, 昭和 16 年. (p. 1 p. 23).

山本武夫 : 記紀万葉の気候. 読売科学, 3， 1965.

山本武夫：歴史の流れに沿5日本とその周辺の気候の変遷. 地学雑誌, Vol. 76, No. 3, 1967. 